\title{
IDENTITAS MODERN BERBUDAYA PADA KAWASAN PUSAT PERTOKOAN DI KOTA MAUMERE
}

\author{
Ambrosius A. K. S. Gobang ${ }^{1}$, Viktorius Belake Keraf ${ }^{2}$ \\ ${ }^{12}$ Program Studi Arsitektur, Fakultas Teknik \\ ${ }^{12}$ Universitas Nusa Nipa Indonesia \\ 'gobangsony@gmail.com
}

\begin{abstract}
The city of Maumere is a city of pride for past, present and future generations. This is supported by the existence of 3 main gates for the entry and exit of goods and services on the mainland of Flores, all of which lead to the city center, causing social and economic impacts, namely the emergence of a tendency for people with very high consumerism characteristics and the need for space for economic activity. This study aims to examine the shopping area as a representative and identified area that can accommodate the economic activities of the people in Maumere City. The research method used is based on qualitative descriptive, namely examining the socio-culture of the community with various economic activities that trigger the growth of the commercial sector with its supporting facilities. The combination of qualitative and quantitative data can assist in conducting descriptive analysis. The results show that the shopping area of Maumere City requires the support of commercial buildings that meet the standards as a forum for economic activity with a modern, cultured image so that it can answer these economic and socio-cultural needs. Along with the increasing needs for life and business premises, the shopping area needs to be reorganized into a representative trading center for the city of Maumere, including the facades of buildings that are united with the availability of infrastructure facilities and infrastructure, including circulation space and green open spaces of quality and beautifully arranged, comfortable. and modern cultured for all societies.
\end{abstract}

Keywords: identity, shops, Maumere City

\begin{abstract}
Abstrak
Kota Maumere merupakan sebuah kota kebanggaan generasi masa lalu, masa kini dan masa yang akan datang. Hal ini didukung oleh adanya 3 pintu gerbang utama bagi masuk keluarnya barang dan jasa di daratan Flores dimana semuanya bermuara ke pusat kota, sehingga menimbulkan dampak sosial dan ekonomi yaitu munculnya kecenderungan masyarakat dengan karakter konsumerisme yang sangat tinggi dan kebutuhan akan ruang bagi aktivitas ekonomi tersebut. Penelitian ini bertujuan untuk mengkaji kawasan pertokoan sebagai kawasan yang representatif dan beridentitas yang dapat mewadahi aktifitas ekonomi masyarakat di Kota Maumere. Metode penelitian yang digunakan berbasis deskriptif kualitatif yaitu mengkaji sosial budaya masyarakat dengan berbagai aktivitas ekonomi yang memicu pertumbuhan sektor komersial dengan fasilitas pendukungnya. Gabungan data kualitatif dan kuantitatif dapat membantu dalam melakukan analisis deskriptif. Hasil penelitian menunjukan kawasan pertokoan Kota Maumere memerlukan dukungan bangunan komersial yang memenuhi standar sebagai wadah kegiatan ekonomi dengan citra modern berbudaya sehingga dapat menjawab kebutuhan ekonomi dan sosial budaya tersebut. Seiring meningkatnya kebutuhan hidup dan tempat usaha, maka kawasan pertokoan perlu ditata kembali menjadi pusat perdagangan kota Maumere yang representatif, meliputi fasad bangunan yang beridentitas menyatu dengan ketersediaan sarana dan prasarana infrastruktur antara lain ruang sirkulasi dan ruang terbuka hijau yang berkualitas dan tertata secara asri, nyaman dan modern berbudaya bagi semua masyarakat.
\end{abstract}

Kata Kunci: identitas, pertokoan, Kota Maumere

\section{Pendahuluan}

Latar Belakang

Kota Maumere merupakan sebuah kota kebanggaan generasi masa lalu, masa kini dan masa yang akan datang. Hal ini didukung pula oleh adanya 3 pintu gerbang utama bagi masuk keluarnya barang dan jasa di daratan Flores yaitu melalui darat, laut dan udara. Untuk mencapai wilayah kota Maumere dari luar Pulau Flores dapat dilakukan melalui Pelabuhan Udara Frans Seda dan melalui laut yang dilayani oleh Pelabuhan L. Say dan Pelabuhan Rakyat di Wuring yang dapat bersandar kapal-kapal relatif besar serta Terminal Bus Madawat maupun Terminal Bus Lokaria. Dari ketiga gerbang penting ini, semuanya bermuara ke pusat kota. Hal ini jelas akan menimbulkan dampak ekonomi maupun sosial yang tinggi. Salah satu yang diamati adalah karakter masyarakat Kabupaten Sikka umumnya dan masyarakat kota 
Maumere khususnya, yaitu kecenderungan konsumerisme yang sangat tinggi. Gaya hidup seperti ini memicu pertumbuhan bidang komersial yang mutlak memerlukan dukungan bangunan komersial yang memenuhi standar sebagai wadahnya sehingga dapat menjawab kebutuhan ekonomi dan sosial budaya tersebut. Seiring meningkatnya kebutuhan hidup masyarakat maupun tempat usaha serta rumah tinggal, maka bangunan ruko merupakan alternatif pilihan yang terbaik dalam pusat kota. Hal ini disebabkan karena selain dapat memenuhi kebutuhan penting dalam memperlancar dunia usaha, ruko juga dinilai telah menjadi pusat bisnis dan perkantoran serta merupakan solusi dari keterbatasan lahan yang ada saat ini. Menurut Soebroto (1983), rumah atau shelter adalah tempat berlindung dan tempat berteduh dari segala cuaca, tempat manusia memenuhi kebutuhan hidupnya dan tempat berlangsungnya proses sosialisasi. Toko adalah ruangan atau tempat menjual dan memamerkan barang dan jasa. Jadi rumah toko (ruko) adalah tempat berlindung sebagai hunian tempat tinggal juga sebagai tempat melakukan kegiatan komersial yang berupa pertokoan.

Secara umum dapat dilihat bahwa pusat pertokoan Kota Maumere dalam kondisi semrawut. Hal ini terbukti dengan tidak adanya penerapan aturan GSB (garis sempadan bangunan), Garis Sempadan Jalan, Garis Sempadan Sungai, rendahnya kwantitas dan kualitas ruang terbuka hijau, tidak ada area parkir, tidak ada pedestrian dan beberapa masalah lain seperti drainase yang tidak berfungsi lagi. Masalah lain diantaranya sering terjadi kemacetan, kecelakaan dan meluapnya air limbah hingga ke jalan raya. Bagian muka atau wajah bangunan yang dikenal dengan istilah fasade memang tak ubahnya seperti wajah manusia. Dengan melihat fasade sedikit banyak kita bisa mengetahui karakter suatu bangunan. Fasade adalah pencipta kesan yang pertama dan terdepan bagi sebuah karya arsitektur (Akmal, 2007:4). Adapun masalah lain yaitu bangunan ruko yang sederhana kurang menarik minat pengunjung. Ini menyebabkan tidak adanya kesenadaaan deret ruko dalam hal ini luas bangunan ruko dan fasade ruko. Fasade yang indah pada pusat kota akan tercermin pada bangunan pertokoan kota Maumere yang mana bila ditata dengan baik dan dirancang dengan gaya arsitektur modern dan beridentitas dapat menarik minat dan membuat masyarakat menjadi betah saat melakukan aktivitas ekonomi.
Kawasan ini menjadi lebih menarik minat berbelanja masyarakat, karena juga didukung oleh keberadaan sebuah ruang terbuka hijau di tengah kawasan yaitu RTH Taman Monami (Monumen Tsunami).

Ruang Terbuka Hijau menunjang kelestarian air dan tanah, RTH di tengah perkotaan dapat berfungsi meningkatkan kualitas lansekap kota. Namun sampai saat ini RTH pada kawasan pertokoan kota Maumere belum sesuai dengan harapan yaitu terwujudnya ruang yang nyaman, produktif dan berkelanjutan walaupun sudah mendapat intervensi dalam perencanaan dan perancangannya. Oleh karena itu semua bagian ini merupakan unsur awal pembentukan kota modern yang secara khusus terinspirasi melalui fasade bangunan perdagangan, dan secara umum melalui fasade Kota Maumere itu sendiri maka tak berlebihan jika arsitek maupun perencana kota harus menaruh perhatian besar pada perencanaan dan perancangan pertokoan kota Maumere ini. Sebagian besar respon publik terhadap sebuah produk arsitektur perkotaan muncul ketika mereka melihat dan menikmati fasilitas maupun sarana infrastruktur, sirkulasi dan fasadenya. Hal ini tidak hanya berlaku untuk bangunan publik saja, tetapi juga bangunan yang sifatnya lebih privat, yaitu rumah tinggal. Kawasan Ruko merupakan sekumpulan bentuk dan model bangunan dimana ciri utamanya adalah adanya suatu bangunan yang dapat mengakomodir kepentingan usaha sekaligus sebagai rumah tinggal, sirkulasi yang baik dan fasilitas yang memadai. Ruko sebagai tempat usaha sekaligus rumah tinggal merupakan satu bangunan dengan dua kepentingan dasar yang berbeda-beda sesuai dengan fungsinya.

Desain kawasan pertokoan yang meliputi gerbang pertokoan sebagai entrance kawasan dan sebagai jembatan penyeberangan dengan menampilkan ornamen identitas kota, bangunan ruko dengan fasade minimalis modern beridentitas, mengoptimalisasi sirkulasi kawasan pertokoan (pedestrian, sirkulasi kendaraan), mengoptimalisasi ruang terbuka hijau serta sarana infrastruktur pendukung lainnya (drainase, jaringan listrik/telepon, jaringan air bersih) dan penyediaan tempat sampah yang memadai. Adapun tiga unsur pembentuk yaitu fasade bangunan pertokoan (ruko), ruang sirkulasi kawasan dan ruang terbuka hijau menjadi aspek penting dalam membentuk citra modern berbudaya sesuai dengan identitas sosial masyarakat Sikka 
khususnya dan masyarakat NTT umumnya. Pembentukan fasade bangunan ruko modern akan ditunjang dengan ketersedian ruang sirkulasi yang memadai sebagai penunjang aksesibilitas orang dan kendaraan serta didukung dengan alternatif ruang untuk interaksi sosial (mengadaptasi karakter masyarakat yang gemar bersosialisasi) yang nyaman dan asri akan terjadi di RTH yang telah ada di kawasan pusat pertokoan Kota Maumere ini.

\section{Tujuan Penelitian}

Penelitian ini bertujuan untuk untuk mengkaji kawasan pertokoan sebagai kawasan yang representatif dan beridentitas yang dapat mewadahi aktifitas ekonomi masyarakat di Kota Maumere.

\section{Manfaat Penelitian}

Penelitian ini dapat bermanfaat sebagai bentuk sumbangsih pemikiran bagi pemangku kebjakan dalam mewujudkan suatu kawasan pusat pertokoan yang representatif, beridentitas, dengan ciri modern berbudaya menyatu dengan ketersediaan sarana dan prasarana infrastruktur yang berkualitas dan tertata secara asri bagi semua masyarkat.

\section{Metodologi Penelitian}

Pendekatan yang dipakai adalah pendekatan kualitatif dengan paradigma naturalistik. Paradigma naturalistik melihat suatu fenomena hanya dapat dipahami maknanya dalam keseluruhan dan tidak dapat dilepaskan dari konteks atau subjek yang diteliti (Moloeng, 2002). Pemilihan pendekatan dalam penelitian ini, yaitu dilakukan pengamatan secara empirik dalam lingkungan kawasan pusat pertokoan sekaligus mengamati perilaku masyarakat dalam aktivitas social ekonomi tersebut. Penelitian ini menggunakan metode deduktif dimana cara analisis dari kesimpulan umum atau generalisasi yang diuraikan menjadi contoh-contoh kongkrit atau fakta-fakta untuk menjelaskan kesimpulan atau generalisasi tersebut. Secara makro pembahasan dilakukan dengan melihat obyek secara teliti, baik mengenai pengetahuan umum tentang ruko, ruang sirkulasi maupun ruang terbuka hijau. Pada pembahasan secara mikro penekanan pada arsitektur modern yang mempengaruhi kualitas tampilan dari bangunan ruko dan ruang sirkulasi kawasan serta tampilan ruang terbuka hijau itu sendiri. Adapun teknik pengumpulan data dilakukan dengan cara studi literatur, interview atau wawancara dan observasi lapangan.

\section{Hasil dan Pembahasan \\ Pertokoan}

Pertokoan adalah tempat atau kompleks toko yang terdapat banyak pedagang yang bertempat tinggal di daerah pertokoan, yang mana kita kenal dengan istilah Ruko atau Rumah Toko. Pertokoan jenis ini tergolong dalam jenis pasar modern dimana pelayanan dilakukan secara mandiri dan dilayani oleh pramuniaga. Istilah ruko sudah sangat familiar ditelinga masyarakat kita, tetapi apa sebenarnya makna dari ruko itu sendiri? Bagaimana fungsinya sebagai bangunan dengan 2 fungsi utama, bagaimana kita memilah-milah ruko dan persyaratan apa saja yang harus kita ketahui sebelum merancang, membangun, membeli, menyewa, menata, dan memanfaatkan ruko? Melihat perkembangan dunia properti yang terjadi saat ini nampaknya properti komersial masih terus menjadi daya tarik bagi para pengembang, salah satunya adalah pengembangan ruko. Adapun fungsi ruko sebagai salah satu bangunan niaga, dimana faktor ekonomi sangat mempengaruhi desain. Ruko merupakan istilah yang berasal dari penggabungan kata rumah dan toko yang disingkat menjadi Ruko. Pengertian ruko sendiri berasal dari pengertian kata rumah sebagai suatu bangunan yang digunakan sebagai tempat tinggal untuk keluarga, dan pengertian kata toko sebagai suatu bangunan yang mewadahi aktivitas manusia dalam melakukan kegiatan komersil yang didalamnya terkandung nilai ekonomi seperti menjual barang dan jasa (Amin dkk, 2009 : 1).

Kata ruko merupakan singkatan dari "rumah dan toko" adalah suatu bangunan gedung yang digunakan untuk mengembangkan fungsi ganda didalam suatu kehidupan, yaitu sebagai wadah menjalankan kegiatan rumah tinggal dan tempat usaha (dagang). Ruko bisa dibedakan menjadi 2 yaitu Ruko dengan arsitektur bangunan bermuka 1 dan ruko dengan arsitektur bangunan bermuka 2. Dari proses pengadaan, ruko juga bisa dibedakan menjadi 2 yaitu pengadaan secara private production dan pengadaan secara massproduction. Selain itu dari sisi lokasi pembangunan, ruko bisa dibedakan pula menjadi 2 yaitu ruko di kawasan perdagangan (pusat kota atau suatu blok tersendiri) dan di kawasan perumahan. Untuk kawasan ruko itu sendiri, hal yang paling utama adalah sirkulasi kendaraan dan sirkulasi manusia, yang harus diperhatikan dan 
direncanakan sesuai dengan jenis kendaraan dan jumlah kendaraan keluar dan masuk kawasan ruko (kawasan yang sudah ada menjadi patokan) dan juga rata-rata jumlah pengunjung atau konsumen maksimal per jam, sehingga fasilitas pendukung lain harus dikembangkan menjadi lebih baik.

\section{Sirkulasi}

Sirkulasi pada kawasan ruko memang menjadi hal yang paling utama diperhatikan. Hal ini karena pengguna jalan (kendaraan dan pejalan kaki) memiliki mentalitas yang tidak bisa mendukung dan memanfaatkan apa yang telah ada, maka bagaimana kita merubah mentalitas itu dengan menata sirkulasi yang sudah ada dengan cara merenovasi dan mengoptimalisasi pola sirkulasi menjadi lebih baik. Sirkulasi adalah prasarana penghubung vital yang menghubungkan berbagai kegiatan dan penggunaan dalam sebuah tapak. Sirkulasi dapat juga digambarkan sebagai satusatunya cara seseorang untuk bisa mengalami sepenuhnya tapak dalam tiga dimensi. Pengalaman berbeda-beda saat menelusuri sebuah tapak, dapat diciptakan melalui perubahan-perubahan dalam sistem sirkulasinya. Sistem sirkulasi menggambarkan seluruh pola-pola pergerakan kendaraan, barang, dan pejalan kaki di dalam dan keluar-masuk tapak. Selain itu, sistem sirkulasi dalam tapak juga menghubungkan tapak tersebut dengan jaringan sistem sirkulasi di luar tapak. Sirkulasi sangat berperan penting dalam perencanaan dan perancangan suatu kawasan, terlebih kawasan ruko sebagai salah satu pusat aktivitas masyarakat di tengah kota.

\section{Ruang Terbuka Hijau}

Secara definitif, Ruang Terbuka Hijau (Green Openspaces) adalah kawasan atau areal permukaan tanah yang didominasi oleh tumbuhan yang dibina untuk fungsi perlindungan habitat tertentu dan atau sarana lingkungan kota dan atau pengamanan jaringan prasarana dan atau budidaya pertanian. Selain untuk meningkatkan kualitas atmosfer, menunjang kelestarian air dan tanah, Ruang Terbuka Hijau (Green Openspaces) di tengah-tengah ekosistem perkotaan juga berfungsi untuk meningkatkan kualitas lansekap kota. Ruang terbuka hijau yang ideal adalah $30 \%$ dari luas wilayah. Hampir disemua kota besar di Indonesia, Ruang terbuka hijau saat ini baru mencapai $10 \%$ dari luas kota. Padahal ruang terbuka hijau diperlukan untuk kesehatan, arena bermain, olah raga dan komunikasi publik atau interaksi sosial. Pembinaan ruang terbuka hijau harus mengikuti struktur nasional atau daerah dengan standarstandar yang ada. Sebagai contoh, Curitibas adalah sebuah kota di Brazil yang menjadi bukti keberhasilan penataan ruang yang mengedepankan RTH di perkotaan. Melalui berbagai upaya penataan ruang seperti pengembangan pusat perdagangan secara linier ke lima penjuru kota, sistem transportasi dan berbagai insentif pengembangan kawasan, persampahan dan RTH, kota tersebut telah berhasil meningkatkan rata-rata luasan RTH per kapita dari $1 \mathrm{~m} 2$ menjadi $55 \mathrm{~m} 2$ selama 30 tahun terakhir. Sebagai hasilnya kota tersebut sekarang merupakan kota yang nyaman, produktif dengan pendapatan per kapita penduduknya yang meningkat menjadi dua kali lipat. Hal tersebut menunjukkan bahwa anggapan pengembangan RTH yang hanya akan mengurangi produktivitas ekonomi kota tidak terbukti.

Melihat kenyataan tersebut tampaknya kebutuhan ruang terbuka yang tidak hanya mengedepankan aspek keleluasaan, namun juga aspek kenyamanan dan keindahan di suatu kota sudah tidak dapat dihindari lagi, walaupun dari hari ke hari ruang terbuka hijau kota menjadi semakin terdesak. Beberapa penelitian menjelaskan bahwa ruang terbuka hijau tidak boleh kurang dari $30 \%$ (Shirvani, 1985), atau $1.200 \mathrm{~m} 2$ tajuk tanaman diperlukan untuk satu orang. Di Surabaya, kebutuhan ruang terbuka hijau yang dicanangkan oleh Pemerintah Daerah sejak tahun 1992 adalah 20-30\%. Sementara kondisi eksisting ruang terbuka hijau baru mencapai kurang dari $10 \%$ (termasuk ruang terbuka hijau pekarangan). Hasil studi yang dilakukan oleh Tim Studi dari Institut Teknologi 10 November Surabaya tentang Peranan Sabuk Hijau Kota Raya tahun 1992/1993 menyebutkan bahwa luas RTH berupa taman, jalur hijau, makam, dan lapangan olahraga adalah + 418,39 $\mathrm{Ha}$, atau dengan kata lain pemenuhan kebutuhan RTH baru mencapai 1,67 m2/penduduk. Jumlah ruang terbuka hijau tersebut sangat tidak memadai jika perhitungan standar kebutuhan dilakukan dengan menggunakan hasil proyeksi Rencana Induk Surabaya 2000 saat itu yaitu 10,03 m2/penduduk. Di Jogyakarta, luas ruang terbuka hijau kota berdasarkan hasil inventarisasi Dinas Pertamanan dan Kebersihan adalah $51.108 \mathrm{~m} 2$ atau hanya sekitar 5,11 Ha (1,6\% dari luas kota) yang terdiri dari 62 taman, hutan kota, kebun raya dan jalur hijau. Bila jumlah luas tersebut dikonversikan dalam angka rata-rata kebutuhan penduduk, maka setiap penduduk Yogyakarta hanya menikmati 0,1 $\mathrm{m} 2$ ruang terbuka hijau. Dibandingkan dengan dua kota yang telah disebutkan di atas, barangkali 
pemenuhan kebutuhan ruang terbuka hijau bagi penduduk di Kota Maumere lebih rendah.

\section{Pembahasan}

Kabupaten Sikka secara geografis terletak antara 806'36"LS-8048'0'LS dan 121040'12'BT122041'24"BT. Kondisi topografis Kabupaten Sikka dikelompokkan dalam satuan luas per interval kontur (ketinggian dari permukaan laut), didominasi oleh wilayah dengan ketinggian $>500$ m, yakni 42,91 \% dari luas wilayah daratan. Secara administrasi Kabupaten Sikka berbatasan dengan :

$\begin{array}{ll}\square \text { Sebelah Utara } & \text { : Laut Flores } \\ \square \text { Sebelah Timur } & \text { : Kabupaten Flores Timur } \\ \square \text { Sebelah Selatan } & \text { : Laut Sawu } \\ \square \text { Sebelah Barat } & : \text { Kabupaten Ende }\end{array}$

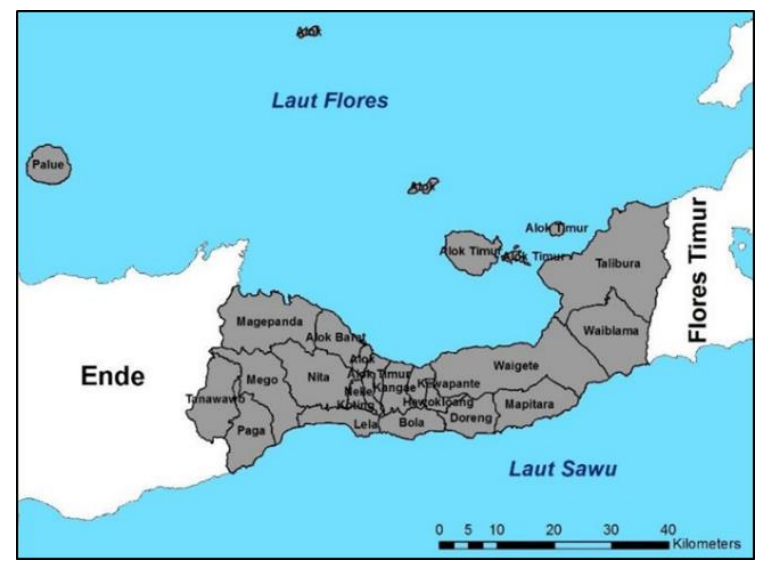

Gambar 1. Peta Administrasi Kabupaten Sikka

Sumber: BPS Kabupaten Sikka

Lokasi site terletak di tengah Kota Maumere yaitu di Kecamatan Alok, Kabupaten Sikka, Pulau Flores, Propinsi Nusa Tenggara Timur. Kecamatan Alok terletak antara 80.2280.55 LS dan 1210,55-1220,40 BT. Luas wilayah daratan Kecamatan Alok adalah 1.731,91 km2 terdiri dari bagian daratan di pulau Flores 1.614,80 $\mathrm{km} 2$ dan gugusan 17 pulau di sebelah utara seluas $117,11 \mathrm{~km} 2$.

Kawasan perdagangan Kota Maumere yang menjadi lokasi penelitian ini hanya mencakup sepanjang Jalan Raja Centis di Kelurahan Kota Baru, Kecamatan Alok dengan lingkup batasan sebagai berikut :

Thomas

$\square$ Utara berbatasan dengan jalan Don

Ahmad Yani
$\quad \square$ Timur berbatasan dengan jalan Moa

Selatan berbatasan dengan jalan Jend.

Toda

Barat berbatasan dengan jalan sungai
Luas keseluruhan kawasan pertokoan \pm $73.175,65 \mathrm{~m}^{2}$ dan luas kawasan penelitian yang meliputi beberapa obyek kajian yaitu pertokoan, ruang sirkulasi dan ruang terbuka hijau tersebut adalah $\pm 64.078,78 \mathrm{~m}^{2}$.

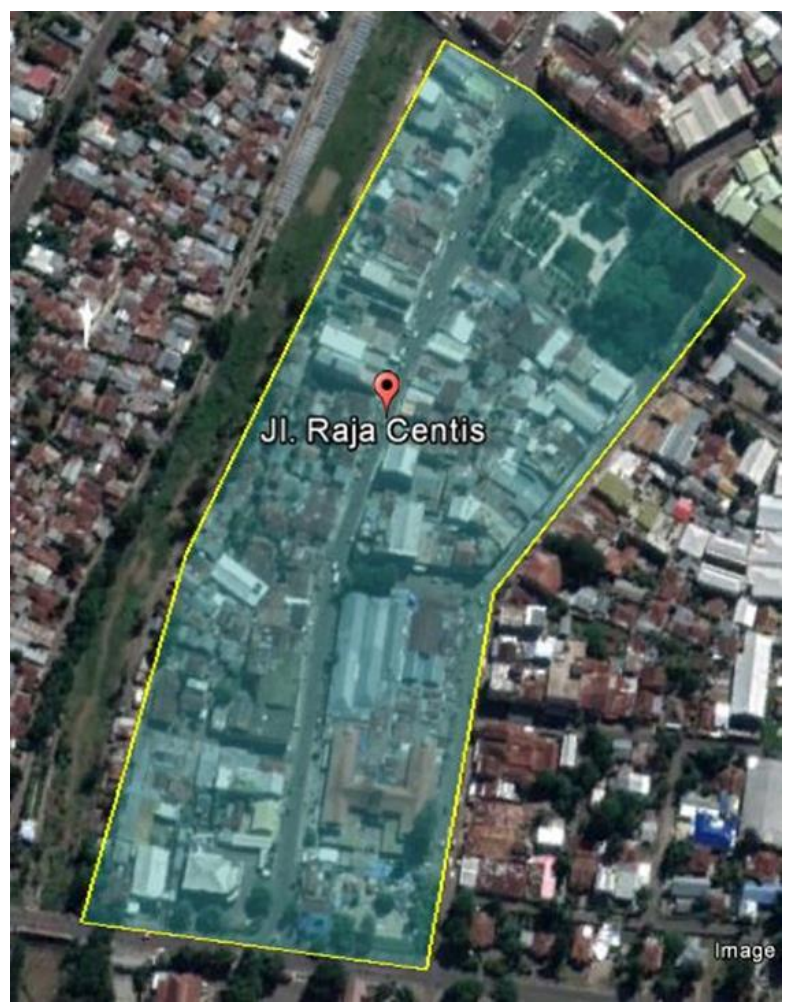

Gambar 2. Lokasi Penelitian

Sumber: Google Earth

\section{Kondisi Umum Pertokoan}

Secara umum kawasan pusat pertokoan Kota Maumere dalam kondisi semrawut, dengan salah satu dasar penilaian yaitu tidak tersedianya areal parkir umum maupun garasi atau carport bagi bangunan ruko.

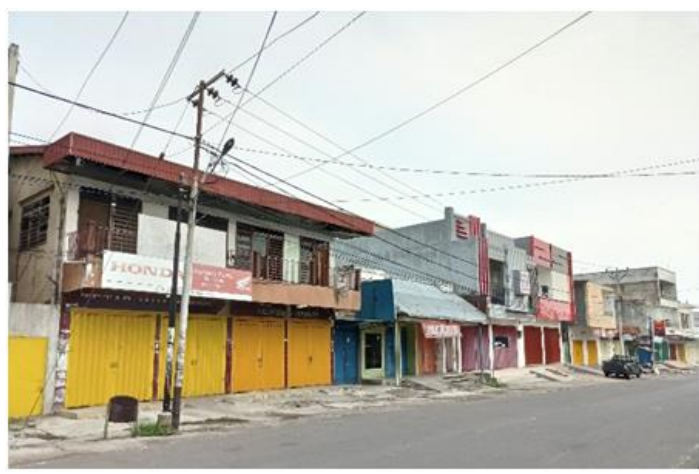
atau kali 


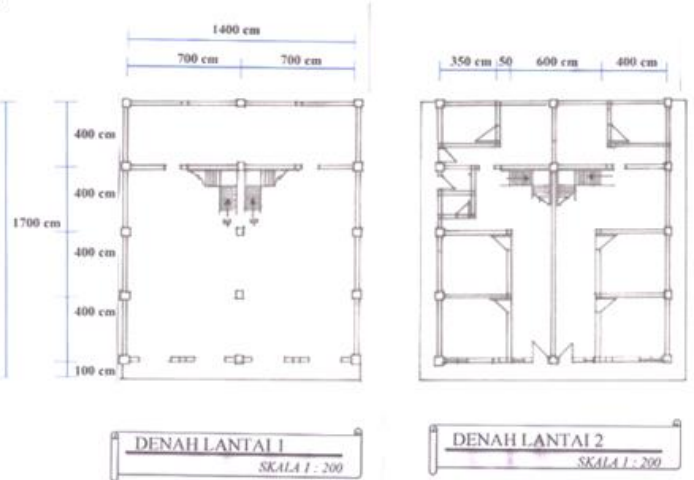

Gambar 3. Tampak dan Denah Ruko 2 Lantai Sumber: Hasil Penelitian

Kondisi ini menyebabkan kemacetan akibat kendaraaan yang parkir pada areal jalan, tidak diterapkan dengan tertib aturan garis sempadan, tidak tersedianya jalur pejalan kaki sehingga ada pengunjung yang berjalan pada areal jalan kendaraan, drainase yang tidak berfungsi secara maksimal, tidak adanya jalur pedestrian hijau yang juga bisa berfungsi sebagai peneduh di depan bangunan ruko karena jalur hijau juga dapat menahan radiasi sinar matahari langsung, kondisi taman kota yang tidak tertata secara baik. Adapun tampak ruko yang sederhana, kurang menarik minat pengunjung dengan pola sirkulasi yang terganggu.

\section{Kondisi Sirkulasi}

Kondisi sirkulasi belum maksimal ini tampak nyata dengan tidak adanya jalur sirkulasi atau pedestrian bagi pejalan kaki, serta pola sirkulasi kendaraan masih belum efisien.

\section{Gambar 4. Kondisi Sirkulasi \\ Sumber: Hasil Penelitian}

Kondisi di lapangan menunjukan bahwa orang cenderung berjalan pada sisa sempadan jalan di depan bangunan ruko. Hal ini disebabkan karena tidak adanya jalur pedestrian. Ada juga yang berjalan pada jalan kendaraan bermotor, karena sempitnya jalan akibat banyaknya pejalan kaki dan kendaraaan yang parkir tidak pada tempatnya akan dapat membahayakan manusia dan menyebabkan kemacetan.

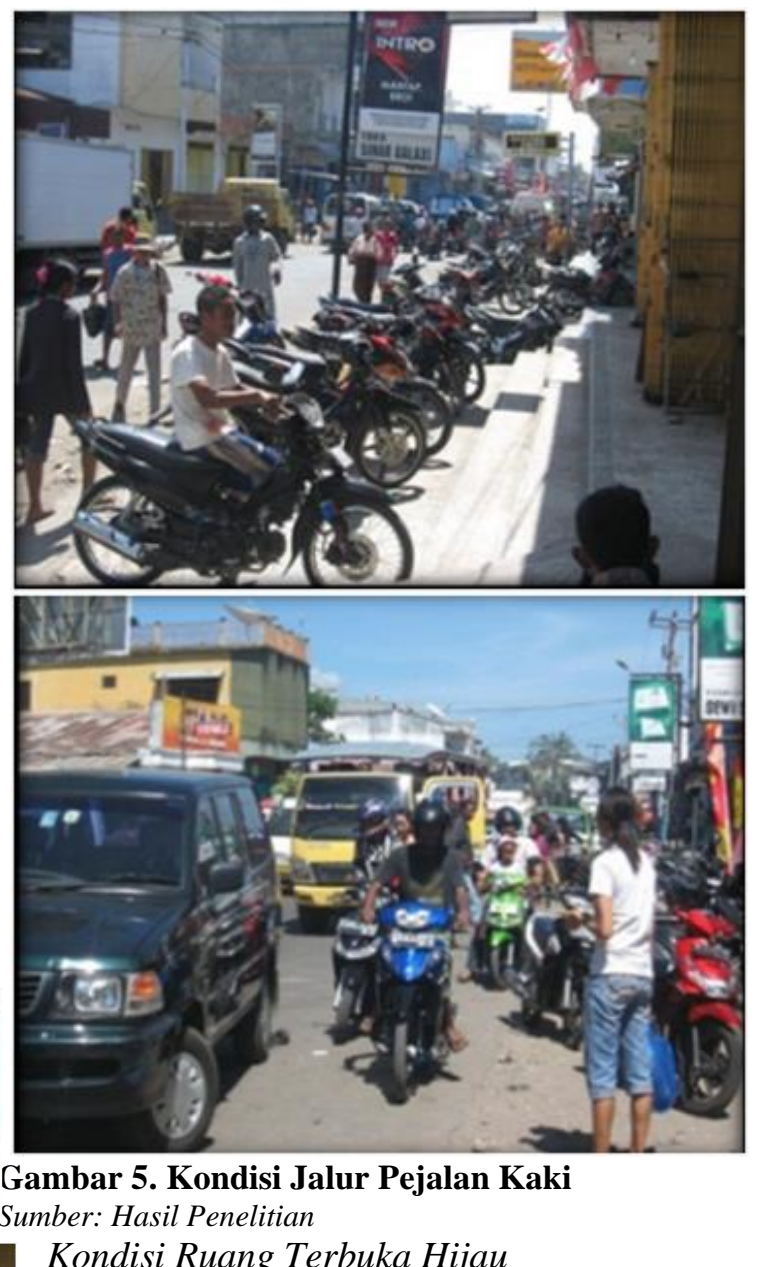

Ruang terbuka hijau saat ini sudah tertata amun belum maksimal mewadahi aktivitas teraksi sosial masyarakat. Terdiri dari beberapa ohon peneduh sehingga udara sekitar masih terasa anas, tidak adanya bangunan pengelolah mengakibatkan pengunjung cenderung mengabaikan tata cara pemakaian fasilitas di dalam RTH. 


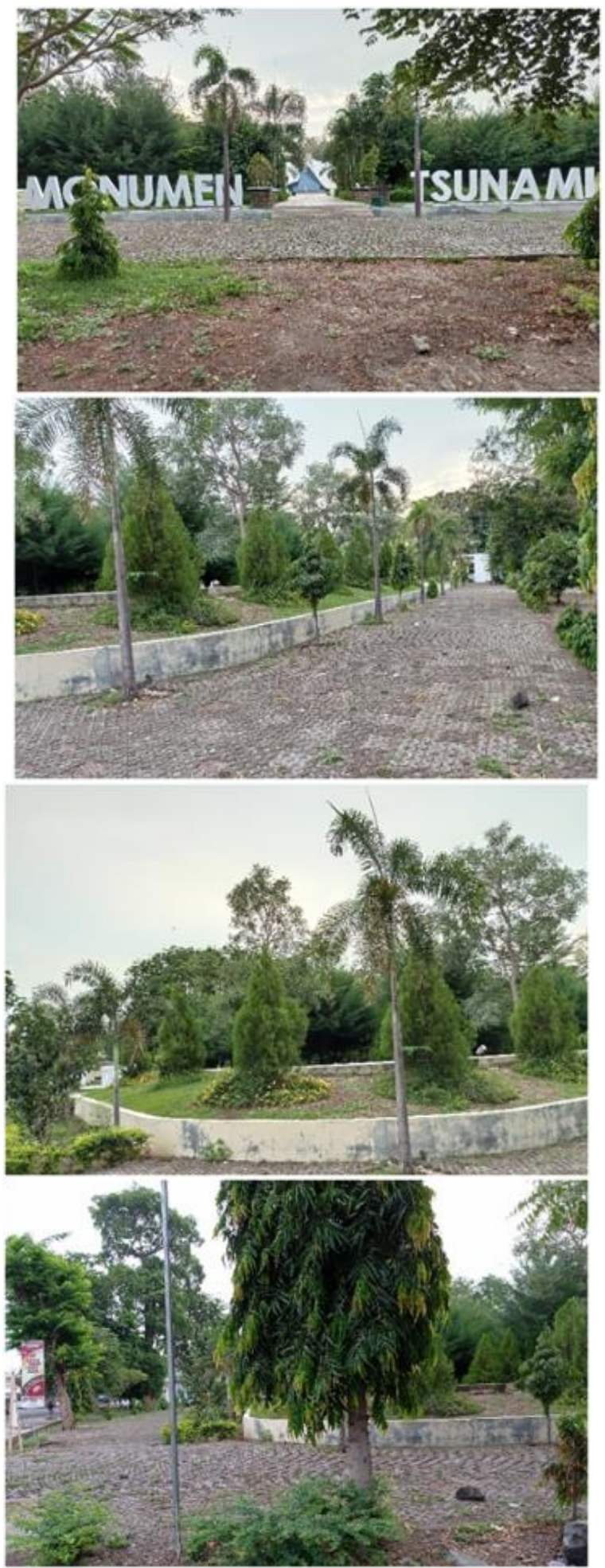

Gambar 6. Kondisi Ruang Terbuka Hijau

Sumber: Hasil Penelitian

\section{Solusi Identitas Modern Berbudaya}

Secara deskriptif kualitatif dapat diuraikan bahwa konsep modern berbudaya diambil dari falsafah aliran arsitektur modern yang diterapkan pada fisik bangunan, khususnya pada fasad pertokoan, ruang sirkulasi dan ruang terbuka hijau yang dipadukan dengan aspek non fisik yaitu budaya masyarakat setempat. Aspek budaya lebih kepada sikap atau kebiasaan masyarakat Kota
Maumere yang ramah, terbuka dan selalu gemar bersosialisasi di berbagai jenis wadah ruang interaksi.

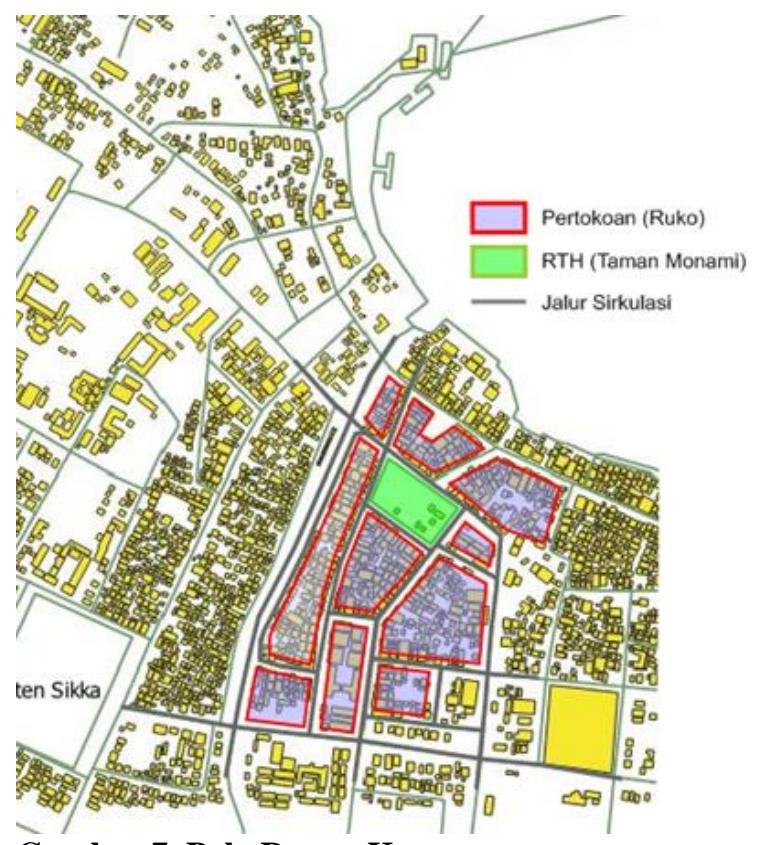

Gambar 7. Pola Ruang Kawasan

Sumber: Hasil Analisis

Keberhasilan konsep ini terletak pada keterpaduan hubungan setiap fungsi ruang dan optimalisasi pemaanfaatan ruang yaitu kegiatan jual-beli di pertokoan dengan aksesibilitas yang nyaman pada setiap fungsi dan akhirnya memilih ruang berinteraksi dan bersosialisasi pada ruang terbuka hijau di dalam kawasan pusat pertokoan Kota Maumere ini. Oleh karena itu tampak fisik pada fasade pertokoan menunjukan kesan modern, sedangkan pola interaksi sosial pada ruang sirkulasi terlebih pada ruang terbuka hijau akan menunjukan identitas yang berbudaya tersebut.

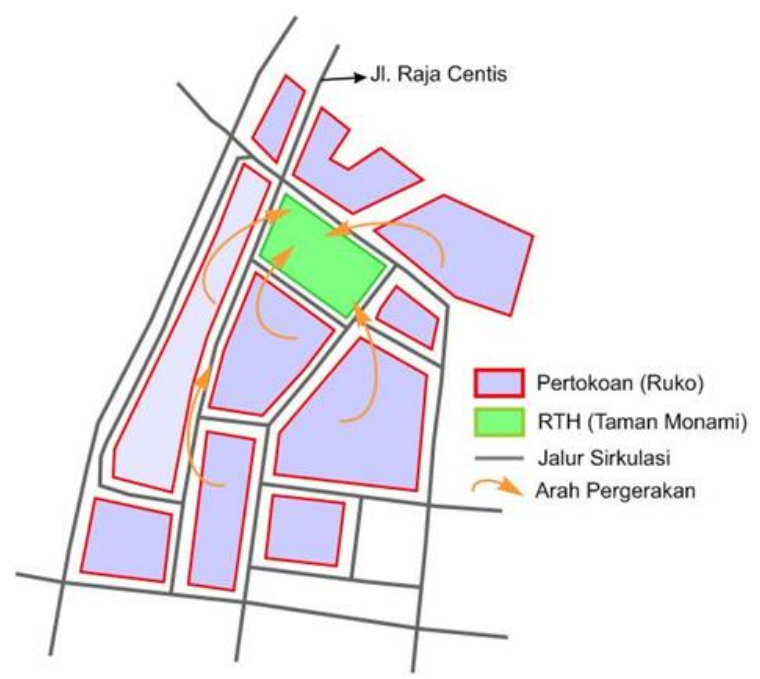

Gambar 8. Orientasi Pergerakan

Sumber: Hasil Analisis 
Pengguna fasilitas pada kawasan pusat pertokoan ini adalah para pengunjung dan para pemilik yang mengelola tempat usaha toko.

\section{- Pengunjung}

Biasanya para pengunjung datang dengan tujuan berbelanja, mengantar, menjemput, sekedar jalan-jalan, duduk dan beristirahat. Untuk itu kebutuhan para pengunjung dengan pola pergerakan yaitu saat Datang - Menuju tempat parkir - Masuk toko - Membeli - Keluar toko Menuju toko lain atau menuju taman - Kembali ke tempat parkir - Pulang. Disamping kelengkapan kebutuhan, aspek kenyamanan menjadi sangat penting, maka ketersediaan ruang yang representatif sangat mutlak antara lain sirkulasi yang tidak membingungkan, ruang kawasan memberikan rasa nyaman dan perlu adanya ruang terbuka hijau sebagai wadah interaksi sosial masyarakat.

- Pemilik atau Pengelola Toko

Pengelola hanya mengawasi penghunjung, menjaga keamanan dan ketertiban, mengatur dan mengawasi kendaraan beroda yang masuk dan keluar areal parker.

\section{Kawasan Pusat Pertokoan}

Penempatan bangunan Ruko sepanjang jalan Raja Centis dengan pola linear atau memanjang, dengan maksud pemanfaatan dan penggunaan ruang site lebih optimal. Fungsi Ruko sendiri mengakomodir kegiatan dan kebutuhan seluruh anggota masyarakat ataupun keluarga penghuni rumah tinggal. Konsep tampilan bangunan ruko adalah minimalis modern dengan elemen-elemen estetis. Sepanjang jalan Raja Centis bagian barat terdapat deret ruko tipe 1 , sedangkan bagian timur terdapat deret ruko tipe 2 .

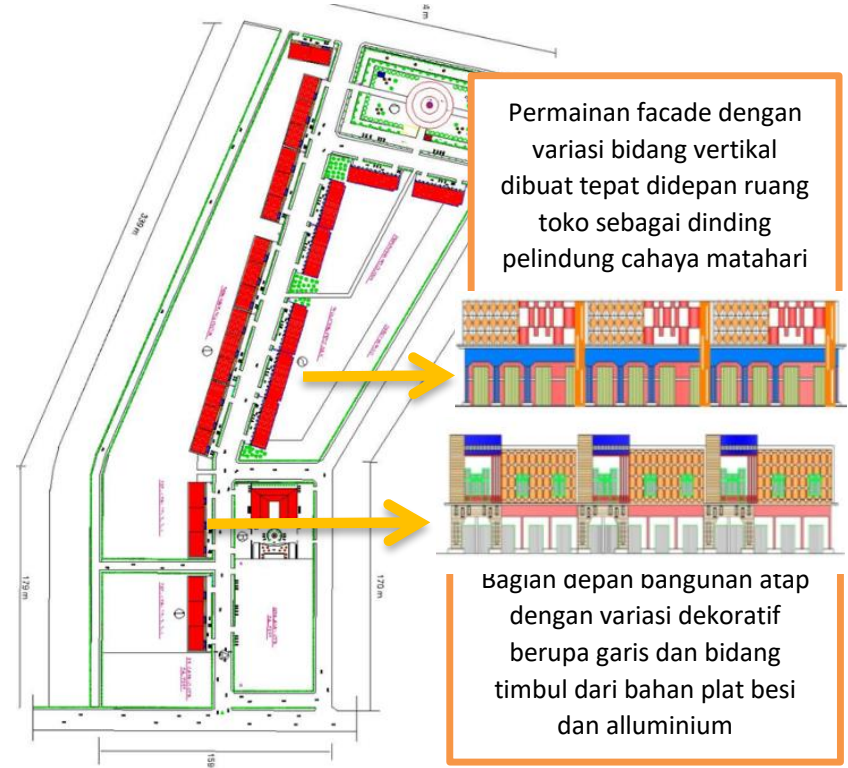

Gambar 9. Tema Penataan Kawasan

Sumber: Hasil Analisis

Adapun beberapa konsepnya dapat dijelaskan sebagai berikut:

- Memasuki kawasan pertokoan kota Maumere melalui gerbang pertokoan

- Sepanjang jalan Raja Centis bagian barat terdapat deret ruko tipe 1, sedangkan bagian timur terdapat deret ruko tipe 2 .

- Pasar tradisional terletak disebelah utara swalayan kota Maumere yang dilengkapi dengan areal parkir umum.

- Paling utara site perancangan ini terdapat taman kota

- Sepanjang deret ruko, taman, dan pasar tradisional terdapat pedestrian, drainase, jalur hijau, dan bak sampah.

\section{Kesimpulan}

Dalam upaya mencari idealnya pelayanan suatu kawasan ekonomi khusunya pada sektor perdagangan modern maka penataan fisik kawasan pusat pertokoan Kota Maumere dapat dipadukan dengan karakter budaya masyarakat untuk mendapatkan sebuah konsep identitas modern berbudaya. Hal ini merupakan upaya menciptakan suatu kawasan pertokoan dengan atsmofer baru yaitu tampilan deret ruko yang berfacade modern dan mampu mengakomodir kegiatan jual beli, mampu mengakomodir semua kegiatan masyarakat didalamnya, pola sirkulasi yang nyaman dan mengoptimalisai pemanfaatan ruang terbuka hijau. Kawasan pusat pertokoan Kota Maumere adalah suatu kawasan yang menyiapkan dan menunjang kebutuhan hidup masyarakat sehingga keberadaannya perlu mendapat perhatian 
dengan cara menata kembali kawasan pertokoan kota Maumere yang bertujuan untuk menciptakan suatu kawasan yang representative, beridentitas dengan ciri modern menyatu dengan ketersediaan sarana prasarana infrastruktur yang berkualitas dan tertata secara asri bagi semua masyarakat.

\section{Referensi}

1. Amin, Choirul,dkk. 2009. Desain Ruko. Yogyakarta : Penerbit Andi.

2. Akmal, Imelda. 2007. Fasade. Jakarta : Penerbit PT.Gramedia Pustaka Utama.

3. Gatot, Hadiyanto. 2012. Kreatif Mendesain Fasad Rumah Modern. Jakarta : Penerbit Kawan Pustaka.

4. Manual Kapasitas Jalan Indonesia, Direktorat Jenderal Bina Marga, 1997.

5. Marlina, Endy 2008. Panduan Perancangan Bangunan Komersial. Yogyakarta : Penerbit Andy.

6. Moleong, Lexy J. 2002. Metode Penelitian Kualitatif. Bandung: Penerbit PT Remaja Rosdakarya.

7. Pingkan, W. 2013. Penataan Kawasan. Retrieved March 7, 2018, from http://penyuluhanpembangunan.blogspot. co.id/2013/11/prinsip-dasarpenataankawasan-penataan.html

8. Primayudha, N. 2015. Tinjauan Pembentukan Kawasan Heritage Budaya Kampung Glam di Singapura dengan Pendekatan Analisis Morfologi dan Tipologi Bangunan. Jurnal Itenas Rekarupa, 3, 34-40.

9. Shirvani, Hamid. 1985. The Urban Design Process. Van Nostrand Reinhold: New York

10. Soebroto, Endah Parwati. 1983. "Aspekaspek Sosial Psikologis Pada Permukiman Berpenghasilan Rendah di Kota-kota Besar." Disajikan pada Seminar Habitat Nasional I Ikatan Arsitek Indonesia Tanggal 24-26 Maret 1983.

11. Tamin, Ofyar Z. 1997. Perencanaan dan Pemodelan Transportasi. Bandung: Penerbit ITB.

12. Yunus, Hadi S. 2000. Struktur Tata Ruang Kota. Yogyakarta: Penerbit Pustaka Pelajar. 